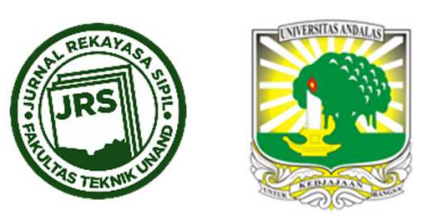

JURNAL REKAYASA SIPIL (JRS-UNAND)

Vol. 14 No. 2, Oktober 2018

Diterbitkan oleh:

Jurusan Teknik Sipil, Fakultas Teknik, Universitas Andalas (Unand)

ISSN (Print) : 1858-2133

ISSN (Online) : 2477-3484

http://jrs.ft.unand.ac.id

\title{
TINJAUAN PERUBAHAN TATA GUNA LAHAN TERHADAP LIMPASAN PERMUKAAN KASUS : DAS BATANG ARAU PADANG
}

\author{
NURHAMIDAH $^{1}$, AHMAD JUNAIDI $^{2}$, MUHAMMAD KURNIAWAN $^{3}$ \\ IJurusan Teknik Sipil, Fakultas Teknik,Universitas Andalas (هnurhamidah@ft.unand.ac.id) \\ ${ }^{2}$ Jurusan Teknik Sipil, Fakultas Teknik,Universitas Andalas (ahmadjunaidi@ft.unand.ac.id) \\ ${ }^{3}$ Jurusan Teknik Sipil, Fakultas Teknik, Universitas Andalas (muhammadkurniawano34@gmail.com) \\ Naskah diterima : 9 Oktober 2018. Disetujui: 8 Desember 2018. Diterbitkan : 8 Desember 2018
}

\begin{abstract}
Perubahan tata guna lahan dari tutupan lahan tidak terbangun seperti hutan, sawah dan ladang menjadi tutupan lahan terbangun akan mengakibatkan peningkatan debit banjir. Pengelolaan tata guna lahan di daerah perkotaan sangat diperlukan dalam upaya menekan laju limpasan permukaan. Semakin besar lahan terbangun maka koefisien limpasannya akan semakin besar juga. Koefisien limpasan berbanding lurus dengan laju limpasan permukaan, semakin besar koefisen limpasan maka semakin besar laju limpasan permukaannya. Oleh karena itu banyak sekali hal hal yang harus diperhatikan oleh pemerintahan setempat dalam mengatasi masalah perubahan alih fungsi lahan di DAS Batang Arau. Tinjauan perubahan dilakukan terhadap perubahan tata guna lahan yang terjadi di DAS Batang Arau pada tahun 2006 dan pada tahun 2012. Tinjauan ini berdasarkan gambaran dari pantauan citra satelit kota Padang pada tahun 2006 dan 2012, serta mengestimasi besarnya luas lahan yang ada di DAS Batang Arau menggunakan analisa spasial Sistem Informasi Geografis (SIG). Estimasi luas dimaksudkan agar dapat menghitung perubahan koefisien limpasan yang terjadi pada tahun 2006 dan juga 2012. Koefisien limpasan permukaan pada tahun 2006 sebesar 0.39 dan tahun 2012 adalah sebesar 0.41. Hal ini membuktikan bahwa perubahan tata guna lahan yang terjadi pada tahun 2006 dan tahun 2012 berpengaruh terhadap koefisien limpasan permukaan DAS Batang Arau. Berdasarkan koefisien limpasan, intensitas hujan rencana dan luas DAS Batang Arau didapatkan debit limpasan pada tahun 2006 adalah $327.20 \mathrm{~m} 3 /$ detik dan pada tahun 2012 adalah 339.51 m3/detik. Dapat kita lihat perubahan limpasan permukaan dari tahun 2006 sampai tahun 2012 di DAS Batang Arau adalah $12.31 \mathrm{~m} 3 /$ detik.
\end{abstract}

Kata kunci : Curah Hujan, Tata Guna Lahan, Limpasan Permukaan, Sistem Informasi Geografis

\section{PENDAHULUAN}

Salah satu banjir besar yang pernah terjadi dikota Padang diantaranya adalah pada tanggal 30 Mei 2017 yang merendam 8 kecamatan di Kota Padang dan ratusan orang dievakuasi. Untuk itu diperlukan penelitian apakah perubahan tata guna lahan berpengaruh signifikan terhadap limpasan permukaan di kota Padang. Dalam penelitian ini, diambil kasus pada Daerah Aliran Sungai Batang Arau kota Padang. 
Tujuan dari analisa ini adalah untuk mendefinisikan perubahan tata guna lahan di Kota Padang terhadap koefisien limpasan permukaan, untuk kemudian ditinjau dampaknya terhadap laju limpasan permukaan pada tahun 2006 dan tahun 2012.

Manfaat dari penelitian ini adalah sebagai bahan informasi dan pertimbangan pemerintahan Kota Padang dalam merencanakan tata guna lahan perkotaan berdasarkan limpasan permukaan dan sebagai informasi bagi penelitian yang akan datang.

Data yang digunakan bersumber dari pantauan citra satelit pada tahun 2006 dan 2012. Sedangkan data curah hujan yang digunakan bersumber dari pencatatan tiga stasiun pengukur curah hujan selama 10 tahun pada DAS Batang Arau. Besarnya debit limpasan permukaan pada tahun 2006 dan 2012 akibat perubahan tata guna lahan di DAS Batang Arau kota Padang, diprediksi dengan menggunakan metode Hasper.

\section{STUDI LITERATUR}

\subsection{Tata Guna Lahan}

Perubahan tata guna lahan adalah berubahnya penggunaan lahan dari suatu lahan ke penggunaan lainnya, dan berubahnya fungsi suatu daerah pada kurun waktu yang berbeda. Perubahan fungsi tutupan lahan dari kawasan hutan atau lahan hijau menjadi kawasan lahan terbangun akan mempengaruhi besarnya laju erosi dan sedimentasi di wilayah tersebut dan membuat genangan di kawasan sekitar bisa juga disebut banjir (Alimin, Wicaksono et al. 2017; Negoro and Cholil 2018).

\subsection{Curah Hujan dan Limpasan Permukaan}

Curah hujan adalah jumlah air hujan yang turun pada suatu daerah dalam waktu tertentu. Curah hujan sangat berpengaruh bagi kehidupan di muka bumi.. Jumlah curah hujan dinyatakan dalam inchi atau milimeter $(1$ inchi $=25.4 \mathrm{~mm}$ ). Jumlah curah hujan $1 \mathrm{~mm}$ menunjukkan tinggi air hujan yang menutupi permukaan $1 \mathrm{~mm}$, jika air tersebut tidak meresap ke dalam tanah atau menguap ke atmosfer. Badan metodologi klimatologi dan geofisika (BMKG) menyebutkan curah hujan adalah ketinggian air hujan yang terkumpul pada bidang cukup datar, tidak menguap, tidak meresap, dan sulit untuk mengalir kedalam tanah.Jumlah curah hujan dalam satuan waktu bisa juga disebut sebagai intensitas curah hujan. Satuan yang digunakan adalah $\mathrm{mm} / \mathrm{jam}$.

Limpasan permukaan adalah banyaknya aliran air atau genangan yang terjadi di permukaan pada saat hujan dan pada waktu tertentu Metoda Rasional banyak digunakan untuk sungai - sungai biasa dengan daerah pengaliran yang luas dan untuk perencanaan drainase daerah pengaliran yang sempit (Lestari 2016; Alimin, Wicaksono et al. 2017). Persamaan umum untuk metode Rasional Sebagai berikut :

$$
Q=0.00278 \times C \times I \times A
$$

Dimana Q merupakan Debit Limpasan ( $\left.\mathrm{m}^{3} / \mathrm{jam}\right)$, C adalah Koefisien limpasan permukaan, i adalah Intensitas Hujan (mm/jam) dan A adalah Luas Daerah (Ha)

Metode yang digunakan adalah Metode Haspers. Metode ini diperuntukkan untuk Daerah Aliran Sungainya yang lebih kecil dari $300 \mathrm{~km}^{2}$. DAS Batang Arau pada penelitian ini mempunyai luas sebesar $168.486 \mathrm{~km}^{2}$. 


\subsection{Sistem Informasi Geografis}

Secara umum pengertian Sistem Informasi Geografis (SIG) adalah suatu komponen yang terdiri dari perangkat keras, perangkat lunak, data geografis dan sumberdaya manusia yang bekerja bersama secara efektif untuk memasukkan, menyimpan, memperbaiki, memperbarui, mengelola, memanipulasi, mengintrgrasikan, menganalisa dan menampilkan data dalam suatu informasi berbasis geografis (Nurhamidah, Junaidi et al. 2016).

Proses input data dalam (SIG) adalah fasilitas dalam SIG yang digunakan untuk memasukkan data dan merubah bentuk data yang dapat diterima dan dipakai dalam SIG. Pemasukkan datanya dilakukan dengan 3 cara, yaitu: Scanning adalah proses pengubahan data grafis kontinue menjadi data grafis yang terdiri atas sel-sel penyusun gambar (pixel). Untuk melakukan scanning ini dengan cara portable scanning. Data disimpan dalam bentuk raster. Digitasi adalah proses pengubahan data grafis analog menjadi data grafis digital, dalam struktur vektor. Pada struktur vektor ini data disimpan dalam bentuk titik (point), garis (segmen), atau data poligon secara matematis. Basis data dalam SIG dikelompokkan menjadi 2 yakni, basis data grafis dan basis data atribut.

Pengolahan data. Pengolahan data meliputi semua operasi penyimpanan, pengaktifan, penyimpanan kembali dan pencetakan semua data yang diperoleh dari input data. Pengaturan data, perbaikan, pengurangan dan penambahan juga dilakukan. Fungsi pada subsistem ini adalah untuk membedakan data yang akan diproses dalam SIG. Untuk merubah format data, mendapatkan parameter dan proses dalam pengelolaan dapat dilakukan disini. Upaya evaluasi terhadap subsistem ini perlu terus dilakukan karena merupakan sistem sentral SIG, dimana informasi baru yang akan dihasilkan diproses dalam subsistem ini.

Keluaran (data output). Pada subsistem ini berfungsi untuk memperlihatkan informasi baru dan analisa dari data geografis, baik itu secara kuantitatif maupun kualitatif. Outputnya dapat berupa peta, tabel, atau arsip, yang kemudian dapat disajikan dalam bentuk hardcopy atau cetakan.

\section{METODE PENELITIAN}

Lokasi studi berada di DAS Batang Arau kota Padang, Sumatera Barat. Luas DAS Batang Arau adalah 16846.9 Ha. Kota Padang, terutama DAS Batang Arau juga memiliki tinggi curah hujan yang relatif tinggi yang membuat kerawanan terhadap banjir. Hampir di setiap terjadinya hujan, beberapa daerah di kawasan tersebut akan terendam banjir yang membuat beberapa jalan, rumah sakit, sekolah, dan gedung perkantoran tidak bisa melakukan aktifitas seperti biasanya.

Digitasi peta tata guna lahan DAS Batang Arau dan luasan tutupan lahan pada tahun 2006 menggunakan pemetaan Quantum GIS. Dengan menggunakann Quantum GIS maka kita dapat melakukan digitasi tata guna lahan di DAS Batang Arau dan didapatkan peta digitasi tata guna lahan DAS Batang Arau.

\section{ANALISA DAN PEMBAHASAN}

Peta digitasi tata guna lahan Daerah Aliran Sungai Batang Arau pada tahun 2006 dan 2012 seperti tergambar berikut : 


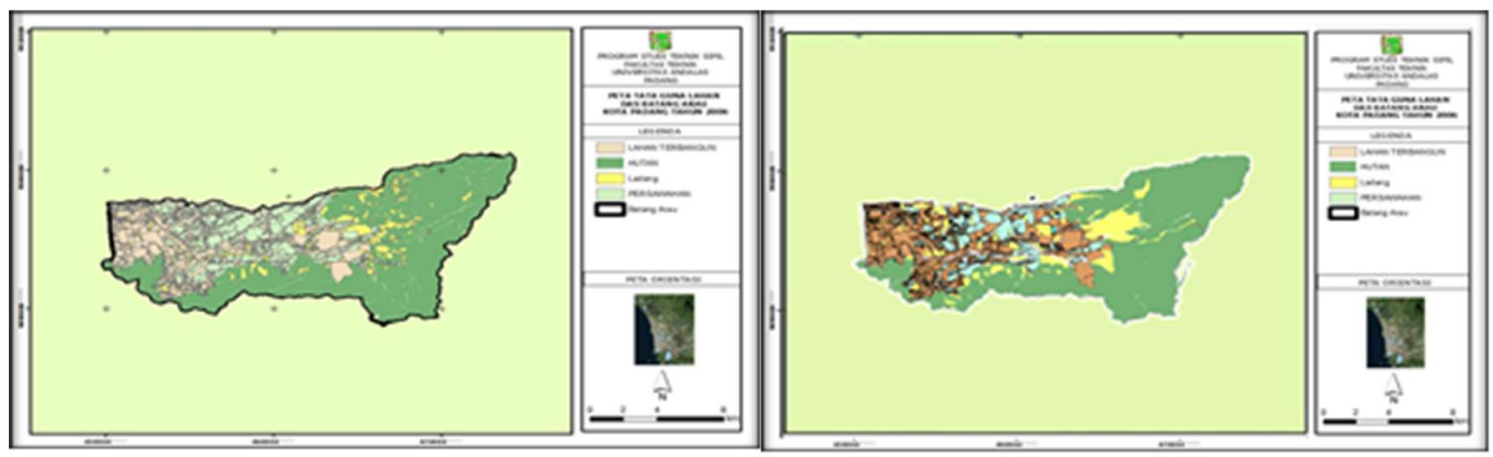

Gambar 1. Peta digitasi tutupan lahan DAS Batang Arau tahun 2006 dan 2012

Berdasarkan peta digitasi diatas, maka dapat diestimasi perubahan tutupan lahan seperti yang tertuang pada table 1 dan Gambar 2 berikut ini:

Tabel 1. Luas tutupan lahan pada tahun 2006 dan 2012

\begin{tabular}{|c|c|c|}
\hline Deskripsi Lahan & $\begin{array}{l}\text { Tahun } 2006 \\
\text { Luas (ha) }\end{array}$ & $\begin{array}{l}\text { Tahun } 2012 \\
\text { Luas (ha) }\end{array}$ \\
\hline Sungai & 297.95 & 297.95 \\
\hline Lahan Terbangun & 3346.24 & 3927.99 \\
\hline Sawah & 2985.39 & 2431.47 \\
\hline Hutan & 8724.61 & 7943.04 \\
\hline Ladang & 1492.70 & 2246.42 \\
\hline Total & 16846.88 & 16846.88 \\
\hline
\end{tabular}

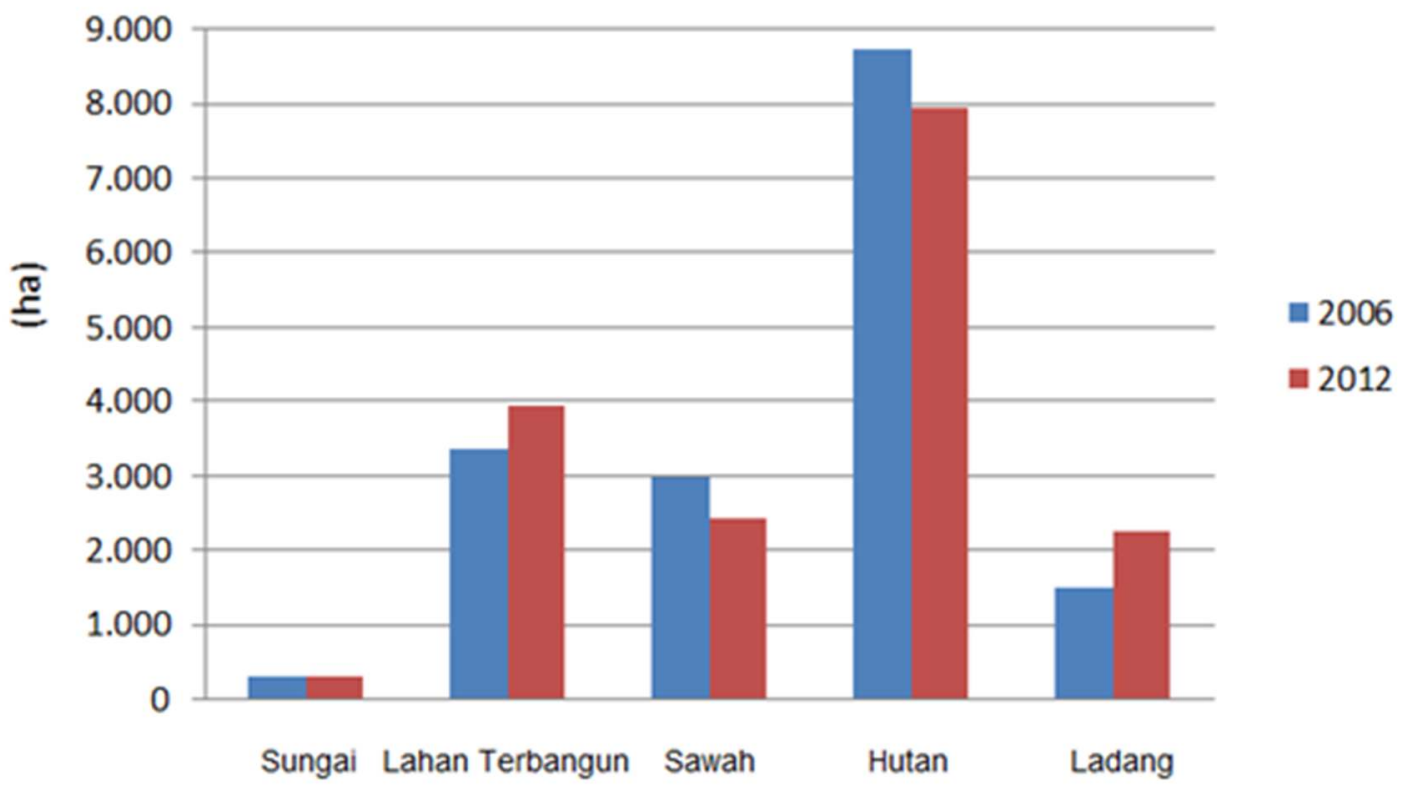

Gambar 2. Grafik penggunaan lahan tahun 2006 dan 2012 
Dari identifikasi yang telah dilakukan terhadap DAS Batang Arau pada tahun 2006 dan 2012, maka nilai koefisien limpasan permukaan DAS Batang Arau dapat dideskripsikan seperti pada table 2 berikut ini :

Tabel 2. Koefisien limpasan permukaan pada DAS Batang Arau (ASCE, 1989)

\begin{tabular}{|c|c|c|}
\hline Karakteristik Lahan & Koefisien C & Nilai C yang digunakan \\
\hline \multicolumn{3}{|l|}{ Lahan Terbangun } \\
\hline Single Family & $0.30-0.50$ & \multirow{5}{*}{$\begin{array}{l}\text { Lahan Terbangun } \\
0.70\end{array}$} \\
\hline Multi unit detached & $0.40-0.60$ & \\
\hline Multi unit attached & $0.60-0.75$ & \\
\hline Residential & $0.50-0.70$ & \\
\hline Apartment & $0.50-0.70$ & \\
\hline \multicolumn{3}{|l|}{ Lahan Pertanian } \\
\hline Datar & $0.31-0.36$ & \multirow{3}{*}{$\begin{array}{l}\text { Sawah } \\
0.35\end{array}$} \\
\hline Sedang & $0.35-0.41$ & \\
\hline Curam & $0.39-0.44$ & \\
\hline \multicolumn{3}{|l|}{ Hutan } \\
\hline Datar & $0.22-0.28$ & \multirow{3}{*}{$\begin{array}{l}\text { Hutan } \\
0.31\end{array}$} \\
\hline Sedang & $0.31-0.36$ & \\
\hline Curam & $0.35-0.41$ & \\
\hline \multicolumn{3}{|l|}{ Taman/Ladang } \\
\hline Datar & $0.32-0.37$ & \multirow{3}{*}{$\begin{array}{l}\text { Ladang } \\
0.37\end{array}$} \\
\hline Medium & $0.37-0.43$ & \\
\hline Curam & $0.40-0.45$ & \\
\hline
\end{tabular}

Untuk mencari nilai koefisien limpasan permukaan (C) total DAS Batang Arau digunakan rumus sebagai berikut :

$$
c=\frac{\mathrm{C} 1 \mathrm{X} \mathrm{A} 1+\mathrm{C} 2 \mathrm{X} \mathrm{A} 2 \ldots \ldots . \mathrm{CN} \mathrm{X} \mathrm{AN}}{\mathrm{A} 1+\mathrm{A} 2+\ldots \ldots \ldots \mathrm{AN}}
$$

Dimana $\mathrm{C}$ merupakan koefisien total tutupan lahan yang ada di DAS Batang Arau, C1,C2,CN adalah koefisien masing masing tutupan lahan dan A adalah luas tutupan lahan

Dengan menggunakan rumus di atas, koefisien limpasan pada tahun 2006 dan 2012 dapat klasifikasikan seperti pada tabel di bawah ini :

Tabel 3. Koefisien limpasan permukaan komposit DAS Batang Arau

\begin{tabular}{|c|c|c|c|c|c|c|c|}
\hline \multirow{2}{*}{$\begin{array}{l}\text { Deskripsi } \\
\text { Lahan }\end{array}$} & \multicolumn{2}{|l|}{2006} & \multirow{2}{*}{$\begin{array}{l}\text { Koefisien } \\
\text { Limpasan } \\
\text { (C) }\end{array}$} & \multicolumn{2}{|l|}{2006} & \multicolumn{2}{|l|}{2012} \\
\hline & Luas (ha) & Luas (ha) & & $\begin{array}{l}\text { CxLuas } \\
\text { (A) }\end{array}$ & Ctotal & $\begin{array}{l}\text { CxLuas } \\
\text { (A) }\end{array}$ & Ctotal \\
\hline Sungai & 297.95 & 297.95 & 0 & 0 & \multirow{6}{*}{0.394} & 0 & \multirow{6}{*}{0.41} \\
\hline $\begin{array}{l}\text { Lahan } \\
\text { Terbangun }\end{array}$ & 3346.24 & 3927.99 & 0.7 & 2342.37 & & 2749.59 & \\
\hline Sawah & 2985.39 & 2431.47 & 0.35 & 1044.89 & & 851.02 & \\
\hline Hutan & 8724.61 & 7943.04 & 0.31 & 2704.63 & & 2462.34 & \\
\hline Ladang & 1492.69 & 2246.42 & 0.37 & 552.29 & & 831.18 & \\
\hline Total & 16846.88 & 16846.88 & & 6644018 & & 6894.13 & \\
\hline
\end{tabular}


Jadi nilai koefisien limpasan permukaan tahun 2006 di DAS Batang Arau adalah 0.39 dan pada tahun 2012 adalah 0.41.

\subsection{Intensitas Hujan di DAS Batang Arau}

Intensitas yang digunakan dalam penelitian ini adalah intensitas hujan rencana 20 tahun. Rumus untuk mencari intensitas hujan sebagai berikut :

$$
i=\frac{\mathrm{R}_{24}}{24}\left(\frac{24}{\mathrm{t}}\right)^{2 / 3}
$$

Dimana i merupakan intensitas hujan ( $\mathrm{mm} / \mathrm{jam}), \mathrm{R} 24$ adalah curah hujan rencana $(\mathrm{mm})$ dan $t$ adalah waktu konsentrasi (jam)

Hasil perhitungan curah hujan rencana pada DAS Batang arau adalah $115.36 \mathrm{~mm}$. Curah hujan Rencana (RT) didapat dari data curah hujan pada 3 stasiun hujan yang ada yaitu Ladang Padi, Simpang Alai dan Komplek PU. Pemilihan distribusi yang dipakai yaitu distribusi log person 3,setelah di lakukan uji Ck dan Cs.Waktu Konsetrasinya (tc) adalah 203.53 menit. Dari data tersebut maka Intensitas hujan rencana 20 tahun adalah :

$$
\begin{aligned}
& i=\frac{115,3597}{24}\left(\frac{24}{203,53 / 60}\right)^{2 / 3} \\
& i=17.72 \mathrm{~mm} / \mathrm{jam}
\end{aligned}
$$

\subsection{Debit Limpasan pada DAS Batang Arau}

Perhitungan Debit limpasan permukaan adalah menggunakan metoda Rasional. Limpasan permukaan adalah aliran air yang mengalir di atas permukaan dikarenakan air hujan yang turun tidak masuk ke tanah dan menjadi aliran air permukaan menuju titik outletnya (sungai atau danau).

a. Debit Limpasan permukaan pada tahun 2006 dan 2012 dengan metode Rasional

Dengan menggunakan metoda rasional limpasan permukaan dapat dihitung berdasarkan koefisien limpasan tahun 2006 adalah 0,394. Intensitas rencana 20 tahun (i) yaitu 17.72 mm/jam. Luas DAS Batang Arau 16848.88 ha.Faktor koreksi untuk luasan hectare adalah 0.00278.Dengan data di atas limpasan permukaan yang di dapat pada tahun 2006 sebagai berikut :

$$
\begin{aligned}
\mathrm{Q}_{20061} & =0.00278 \times \mathrm{C} \times \mathrm{I} \times \mathrm{A} \\
& =0.00278 \times 0.394 \times 17.72 \times 16864.88=327.20 \mathrm{~m}^{3} / \text { detik }
\end{aligned}
$$

Koefisien limpasan tahun 2006 adalah 0.41.Intensitas rencana 20 tahun (I) yaitu $17.72 \mathrm{~mm}$ jam.Luas DAS Batang Arau 16848.88 ha. Faktor koreksi untuk luasan hektar adalah 0.00278. Dengan data di atas limpasan permukaan yang di dapat pada tahun 2006 sebagai berikut :

$\mathrm{Q}_{2012}=0.00278 \times \mathrm{C} \times \mathrm{I} \times \mathrm{A}$

$$
=0.00278 \times 0.41 \times 17.72 \times 16864.88=339.51 \mathrm{~m}^{3} / \text { detik }
$$

b. Debit Limpasan permukaan pada tahun 2006 dan 2012 dengan metode Hasper

Metoda ini digunakan karena Daerah Aliran Sungainya nya lebih kecil dari $300 \mathrm{~km} 2$. DAS Batang Arau pada penelitian ini mempunyai luas sebesar $168.47 \mathrm{~km} 2$. Pada DAS Batang 
Arau, panjang sungainya yaitu $19.83 \mathrm{~km}$, kemiringan sungai adalah 0.014374 dan memiliki luas Area $168.49 \mathrm{~km} 2$.

Nilai kofisien limpasan permukaan $(\alpha)$ pada tahun 2006 adalah $0.39, \beta$ pada tahun 2006 adalah 0.66 , tc yaitu 3.94 mempunyai nilai $91.82 \mathrm{~mm}$ dan nilai q yaitu $6.54 \mathrm{~m} 3 / \mathrm{detik} / \mathrm{km}$ Dari data di atas didapatkan :

$\mathrm{Q}_{2006}=\alpha \times \beta \times \mathrm{q} \times \mathrm{A}$ $=0.39 \times 0.66 \times 6.54 \times 168.49=286.06 \mathrm{~m}^{3} /$ detik

Metoda Hasper juga digunakan pada perhitungan limpasan permukaan tahun 2012. Pada tahun 2012 DAS Batang Arau memiliki koefisien limpasan permukaan ( $\alpha$ ) yaitu 0.41.

Langkah langkah perhitungan limpasan permukaan pada tahun 2012 sama dengan limpasan permukaan pada tahun 2012.Sehingga didapatkan limpasan permukaan pada tahun 2012 sebagai berikut :

$$
\begin{aligned}
\mathrm{Q}_{2012} & =\alpha \times \beta \times \mathrm{q} \times \mathrm{A} \\
& =0.41 \times 0.659 \times 6.54 \times 168.49=296.95 \mathrm{~m}^{3} / \mathrm{detik}
\end{aligned}
$$

Dapat disimpulkan limpasan permukaan juga mengalami kenaikan pada tahun 2006 dan tahun 2012 sebesar $10.89 \mathrm{~m} 3 /$ detik dengan menggunakan metoda Haspers akibat perubahan tata guna lahan DAS Batang Arau.

c. Perbandingan Limpasan permukan metoda Rasional dan metoda Haspers

Dengan menggunakan metoda Rasional dan Metoda Haspers limpasan permukaannya sama - sama meningkat dari tahun 2006 dan tahun 2012 akibat perubahan tata guna lahan di DAS Batang Arau,

Dari hasil pembahasan didapatkan besarnya limpasan pemukaan pada tahun 2006 dan 2012 di DAS Batang Arau dengan menggunakan metoda Rasional dan Metoda Haspers sebagai berikut :

Tabel 4. Debit Limpasan DAS Batang Arau menggunakan metoda Haspers dan Rasional

\begin{tabular}{lll}
\hline \multicolumn{1}{c}{ Tahun } & \multicolumn{2}{c}{ Debit $\mathbf{Q}\left(\mathrm{m}^{3} /\right.$ detik $)$} \\
\hline & Metode Rasional & Metode Hasper \\
\hline 2006 & 327.20 & 286.06 \\
\hline 2012 & 339.51 & 296.95 \\
\hline
\end{tabular}

\section{KESIMPULAN DAN SARAN}

\subsection{Kesimpulan}

Berdasarkan Peta Digitasi Tata Guna Lahan DAS Batang Arau tahun 2006 dan 2012, telah terjadi perubahan tata guna lahan di kawasan tersebut. Hal ini dapat dilihat pada lahan tidak terbangun berupa sawah, ladang dan hutan yang mengalami perubahan fungsi ke lahan terbangun sebesar 581.76 ha. Dari hasil analisis data hujan yang telah dilakukan, telah didapatkan curah hujan maksimum berdasarkan Distribusi Log Person III dengan periode ulang 20 tahun. Nilai curah hujan rencana dengan periode ulang 20 tahun adalah 115.36 $\mathrm{mm}$. Berdasarkan perhitungan dengan persamaan mononobe didapatkan intensitas hujan di DAS Batang Arau adalah $17.72 \mathrm{~mm} / \mathrm{jam}$ dalam periode 20 tahun. 
Penelitian di DAS Batang Arau ini telah mendapatkan perubahan koefien limpasan permukaan yang terjadi pada tahun 2006 dan tahun 2012. Koefisien limpasan permukaan pada tahun 2006 sebesar 0.39 dan tahun 2012 adalah sebesar 0.41. Hal ini membuktikan bahwa perubahan tata guna lahan yang terjadi pada tahun 2006 dan tahun 2012 berpengaruh terhadap koefisien limpasan permukaan DAS Batang Arau.

Berdasarkan koefisien limpasan, intensitas hujan rencana dan luas DAS Batang Arau didapatkan debit limpasan pada tahun 2006 adalah $327.20 \mathrm{~m} 3 /$ detik dan pada tahun 2012 adalah $339.51 \mathrm{~m} 3 /$ detik. Dapat kita lihat perubahan limpasan permukaan dari tahun 2006 sampai tahun 2012 di DAS Batang Arau adalah 12.31 m3/detik.

\subsection{Saran}

Untuk memperoleh hasil yang maksimal maka dibutuhkan beberapa parameter tambahan yang mempengaruhi terjadinya limpasan permukaan, seperti pengaruh pasang-surut air laut dan drainase dan debit banjir sungai rencana. Selain itu disarankan adanya tindakan lanjutan dari hasil tinjauan ini. Tindakan tersebut dapat berupa tindakan teknis maupun non teknis terhadap DAS Batang Arau.

\section{DAFTAR PUSTAKA}

Alimin, M., K. S. Wicaksono, et al. (2017). Estimasi Limpasan Permukaan DAS Mikro Brantas Hulu Kecamatan Bumiaji kota Batu menggunakan Penginderaan Jauh dan Sistem Informasi Grafis. Jurnal Tanah dan Sumberdaya Lahan 2(2): 171-177.

Barus, B danWiradisastraU.S. 2000. Sistem informasi Geografi; Sarana Manajemen Sumber Daya. Bogor: Laboratorium Peginderaan jauh dan Kartografi Tanah Fakultas Pertanian IPB.

Hardanigrum Faridah, dkk,. 2005. Analisis Genangan Air Hujan di Kawasan Delta dengan Menggunakan Penginderaan Jauh dan SIG. Institut Teknologi Sepuluh November. Surabaya.

Lestari, U. S. (2016). Kajian Metode Empiris untuk Menghitung Debit Banjir Sungai Negara di Ruas Kecamatan Sungai Pandan (Alabio). Jurnal Poros Teknik 8(2): 86-96.

Muhammad Subki. (2015). Identifikasi Dan Dampak Perubahan Tata Guna Lahan Terhadap Limpasan Permukaan di Kecamatan Seririt, Buleleng, Bali. Institut Pertanian Bogor, Bogor.

Negoro, S. and M. Cholil. (2018). Estimasi Potensi Limpasan Permukaan dengan Menggunakan Data Penginderaan Jauh dan Sistem Informasi Geografi di Daerah Aliran Sungai Kayan Provinsi Kalimantan Utara, Universitas Muhammadiyah Surakarta.

Nurhamidah, A. Junaidi, et al. (2016). An Immediate Review of Flood Characteristics on Delta Lowland Sumatra using D8 Model Spatial Analysis. International Journal on Advanced Science, Engineering and Information Technology 09(03): 436 - 442.

Prahasta Eddy. (2009). Sistem Informasi Geografis Konsep-Konsep Dasar (Perspektif Geodesi dan Geomatika). Informatika. Bandung.

SNI 19-6502.4-2000 tentangPenamaan Pada Tutupan Lahan. Jakarta.

Undang-Undang Republik Indonesia Nomor 7 Tahun 2004 tentang Definisi Daerah Aliran Sungai. 